\title{
Microbial density and associated physicochemical properties of palm wine in Wilberforce Island, Nigeria
} \author{
Morayo $^{2}$ \\ ${ }^{1}$ Department of Community Medicine, Faculty of Clinical Sciences, Niger Delta University, Wilberforce Island, Bayelsa State, Nigeria \\ ${ }^{2}$ Department of Biological Sciences, Faculty of Science, Niger Delta University, Wilberforce Island, Bayelsa State, Nigeria \\ ${ }^{3}$ Department of Environment, Research and Development, Anal Concept Limited, Elelenwo, Rivers State, Nigeria \\ ${ }^{4}$ Department of Microbiology, Faculty of Science, Bayelsa Medical University, Yenagoa, Bayelsa State, Nigeria
}

Glory Richard ${ }^{1}$, Felix Okponanabofa Youkparigha ${ }^{2}$, Ayobami Omozemoje Aigberua ${ }^{3}$, Sylvester Chibueze Izah" and Edah Oghenetega

\begin{abstract}
This study evaluated the microbial density and concentration of some physicochemical constituents of palm wine sold in Wilberforce Island, Bayelsa State, Nigeria. Samples of palm wine were purchased from 6 locations. Sample from each location was sub-sampled in triplicate, and the density of microbial population was enumerated following standard microbiological procedure. The physicochemical parameters of constituents were determined using standard procedures. Results showed that total heterotrophic bacteria counts, total fungi counts, $\mathrm{pH}$, conductivity, specific gravity, total nitrogen, available phosphorus, magnesium, calcium, potassium and sodium in palm wine ranged from $2.620 \times 10^{4}-1.713 \times 10^{5} \mathrm{CFU} / \mathrm{ml}, 5.867 \times 10^{4}-2.163 \times 10^{5} \mathrm{CFU} / \mathrm{ml}, 3.600-3.767,5750.000-8816.667 \mu \mathrm{S} /$ cm, $0.998-1.010,0.131-0.216 \%, 0.020-0.063 \mathrm{mg} / \mathrm{L}, 6.403-9.592 \mathrm{mg} / \mathrm{L}, 17.788-41.292 \mathrm{mg} / \mathrm{L}, 13.842-15.631 \mathrm{mg} / \mathrm{L}$ and $9.177-11.030 \mathrm{mg} / \mathrm{L}$ respectively. Apart from $\mathrm{pH}$, all other test parameters showed significant discrepancies $(p<0.05)$ in the different samples. The observed variation suggests that different factors are influencing the microbial and physicochemical characteristics of palm wine in the study area. The microbial density was within tolerable limits $\left(10^{4}\right.$ to $\left.10^{5}\right)$ in food as specified by the International Commission on Microbiological Specifications for Foods. The high microbial population suggests the need to regularly evaluate microbial density in palm wine to forestall potential health risks associated with its consumption.
\end{abstract}

\section{Introduction}

Species of Raphia and Elaeis which are geographically diverse in Nigeria, especially in the southern parts, are mostly used for the production of palm wine in Nigeria. The genus Elaeis has oil palm (Elaeis guineensis) as a predominant species that is used for the production of palm oil and palm wine through destructive (uprooting or felling of the oil palm tree prior to production of palm wine) and nondestructive methods (collection of palm wine from the inflorescence which bears fruits without destroying the tree). Despite the abundance of several species of Raphia palm in the Niger Delta, its oil is often underutilized. The palm is predominantly used for production of palm wine, especially in the coastal regions of Bayelsa State. In addition, the other parts of Raphia palm are used for developmental or construction works which includes the building of fish and turtle traps, ropes, as well as floor brushes across coastal communities of Nigeria.

Palm wine is a socially significant drink across cultures of several ethnic groups in different parts of the World, particularly Nigeria. For instance, it is consumed during ceremonies such as funeral, marriage, child naming events, coronation, chieftaincy-title conferment, etc [1]. It is commonly consumed by the young and aged, most especially those living in rural areas. There have been instances of the infusion of palm wine into some herbal medicines used for treating specific ailments in traditional settings across Nigeria [2].

Yeasts are among the predominant microbes found in palm wine. The yeast found in palm wine converts sugar to alcohol through the process of fermentation. As such, the progression of fermentation decreases the sugar content as the alcohol content increases. This is an indication that organisms that are able to ferment palm wine sap are acid-tolerant (acidophilic). These, microbes, can potentially alter the physicochemical properties of palm wine which is essential in terms of quality assessment for human consumption.

Microbes are ubiquitous and have been reported in several food materials and environmental samples. The bacteria species commonly found in palm wine sold in different locations in Nigeria belong to the genera; Chromobacterium, Gluconobacter, Peptostreptococcus, Corynebacterium, Zymomonas, Pseudomonas, Paediococcus, Serratia, Shigella, Vibrio, Salmonella, Micrococcus, Serratia, Micrococcus, Leuconostoc, Listeria, Bacillus, Lactobacillus, Acetobacter, Streptococcus, Escherichia and Staphylococcus, while the yeasts species commonly isolated include Saccharomyces cerevisiae, Saccharomyces globosus, Saccharomyces carlsbengensis, Schizosaccharomyces pombe, Zygo-Sacchraromyces fermentati, Hansenula anomala, Pichia ohmeri, Hanseniaspora uvarum, Kluveromyces marxianus, Candida tropiclis and Candida species [2,3-7]. Some of the yeasts species such as Hanseniaspora uvarum, Saccharomyces globosus, and Saccharomyces carlsbengensis are ethanol-tolerant with adaptive features that enable them thrive in varying degrees of ethanol concentrations [5].

${ }^{*}$ Correspondence to: Izah SC, Department of Microbiology, Faculty of Science, Bayelsa Medical University, Yenagoa, Bayelsa State, Nigeria, Tel: +2347030192466; E-mail: chivestizah@gmail.com

Key words: microbial contaminants, microorganisms, public health, palm wine, quality assessment

Received: March 24, 2020; Accepted: July 06, 2021; Published: July 09, 2021 
Some microbes, especially bacteria are pathogenic with well documented public health implications. Since different microbial isolates are found in palm wine, it is important to ascertain their density in order to determine its fitness for human consumption. Hence, this study aimed at assessing the microbial density and associated physicochemical properties of palm wine in Wilberforce Island, Nigeria

\section{Materials and methods}

\section{Study area}

The study was carried out in Wilberforce Island, Bayelsa State, Nigeria. The Island is made up of few hamlets and about 10 communities with heterogeneous population [8]. The major communities include Oweikorogha, Ikibiri, Ikolo, Bumoudi, Agudama-Ekpetiama, Igbedi, Agorogbene, Ogobiri and Amassoma [8,9]. The major occupations of the indigenous people of the area include farming, fishing and lumbering. However, following the creation of Bayelsa state and establishment of the Niger Delta University; civil service and trading activities, which were generally rudimentary received a boost and have become supplementary sources of livelihood amongst local inhabitants of the area [8]. Two predominant seasons of the area are wet season (occurring between April and October), with a short break around early August, and the dry season which occurs between November and March of the succeeding year. The study area has a major road link with the state capital (Yenagoa). The area has been reported as the second most populated area in Bayelsa state [10].

\section{Sample collections}

Triplicate samples of Raphia palm wine were collected from six different palm wine vendors in Wilberforce Island, Bayelsa state, Nigeria. The samples were preserved in an ice pack and analyzed within 4 hours after collection

\section{Macro nutrients ( $\mathrm{Ca}, \mathrm{Mg}, \mathrm{Na}$ and $\mathrm{K}$ ) analysis}

About $25 \mathrm{~mL}$ of sample (palm wine) was pretreated with $5 \mathrm{~mL}$ of concentrated nitric acid. The samples were prepared following the method previously described by Aigberua and Izah [11]. The resultant diluents and a reagent blank were aspirated into the GBC Avanta PM A6600 flame atomic absorption spectrophotometer, and concentration of the macro nutrients were determined at varying wavelengths [11].

\section{pH determination}

The palm wine sample was stirred with a clean glass stirring rod. About $40 \mathrm{~mL}$ of sample was poured into a glass beaker. With occasional stirring, sample was left to stand for about 1 hour. The $\mathrm{pH}$ meter (HANNA HI 8314 model) was standardized using buffer solutions of 4.0, 7.0 and $10.0 \mathrm{pH}$ units. The $\mathrm{pH}$ was determined following the method previously described by Aigberua and Izah [12].

\section{Specific gravity determination}

Following methods specified in APHA [13] for specific gravity of waste water, sample temperature (T) was recorded and the weights (W) of density bottles measured. The container was filled to mark with palm wine, weighed and recorded as S. Another density bottle was filled to mark with distilled water, weighed and denoted $\mathrm{R}$.

Specific gravity was calculated as:

Specific gravity, $S G=$ (weight of sample/weight of equal volume of water at $\left.4^{\circ} \mathrm{C}\right)=(S-W) /(R-W) \times F$.

Were $\mathrm{F}$ is the temperature correction factor $(0.9975)$ at $25^{\circ} \mathrm{C}$.

\section{Total Oxidized Nitrogen $\left(\mathrm{NO}_{2}^{-}+\mathrm{NO}_{3}^{-}\right)(\mathrm{Cd}$ reduction + spectrophotometric $\mathrm{NO}_{2}^{-}$)}

About $100 \mathrm{~mL}$ of test sample was filtered through $0.45 \mu \mathrm{m}$ membrane filter and the sample $\mathrm{pH}$ was adjusted to 7 using sodium hydroxide $(\mathrm{NaOH})$. Exactly $75 \mathrm{~mL}$ of ammonium chloride-EDTA solution $\left(\mathrm{NH}_{4} \mathrm{Cl}\right.$-EDTA) was added to solution prior to mixing. The homogenized sample was poured into a reduction column and the filtrate collected at the rate of $8.7 \mathrm{~mL} / \mathrm{min}$. The first $10 \mathrm{~mL}$ portion of eluent was discarded. Thereafter, subsequent filtrate was collected in sample flask, and about $2 \mathrm{~mL}$ of color reagent was added to $50 \mathrm{~mL}$ portion of sample prior to mixing. Sample mixture was left to stand for 1 hour after which the concentration of nitrate $\left(\mathrm{NO}_{3}^{-}\right)$was measured in $\mathrm{mg} / \mathrm{L}$ units at $543 \mathrm{~nm}$. A distilled water reagent blank (nitrate-free water) was also analyzed as quality check for any interference.

Another $50 \mathrm{~mL}$ portion of filtered sample was transferred into a $250 \mathrm{~mL}$ conical flask. The $\mathrm{pH}$ was adjusted to 7 using ammonium hydroxide $\left(\mathrm{NH}_{4} \mathrm{OH}\right)$, while $2 \mathrm{~mL}$ of color reagent $(800 \mathrm{ml}$ distilled water $+100 \mathrm{~mL} 85 \%$ phosphoric acid $\left(\mathrm{H}_{3} \mathrm{PO}_{4}\right)+10 \mathrm{~g}$ sulphanilamide $\left.\left(\mathrm{C}_{6} \mathrm{H}_{8} \mathrm{~N}_{2} \mathrm{O}_{2} \mathrm{~S}\right)\right)$ was added and mixed. Sample was allowed to stand for 1 hour. Afterwards, nitrite $\left(\mathrm{NO}_{2}^{-}\right)$concentration was determined in $\mathrm{mg} / \mathrm{L}$ units at a wavelength of $543 \mathrm{~nm}$ [13].

\section{Available phosphorus determination (Ascorbic Acid Method)}

Based on slight modification of phosphorus determination by APHA [13], exactly $50 \mathrm{~mL}$ of sample solution was transferred into a $125 \mathrm{~mL}$ Erlenmeyer flask, and a drop of phenolphthalein indicator was added. About $5 \mathrm{~mL}$ of $5 \mathrm{~N}$ sulphuric acid $\left(\mathrm{H}_{2} \mathrm{SO}_{4}\right)$ solution was added in drops to discharge the red coloration that developed, after which another $8 \mathrm{~mL}$ of combined reagent $(50 \mathrm{~mL}$ of $5 \mathrm{~N}$ sulphuric acid $\left(\mathrm{H}_{2} \mathrm{SO}_{4}\right)+5 \mathrm{~mL}$ potassium antimonyl tartrate $\left(\mathrm{K}(\mathrm{SbO}) \mathrm{C}_{4} \mathrm{H}_{4} \mathrm{O}_{6} \cdot 1 / 2 \mathrm{H}_{2} \mathrm{O}\right)$ $+15 \mathrm{~mL}$ ammonium molybdate solution $\left(\left(\mathrm{NH}_{4}\right)_{6} \mathrm{Mo}_{7} \mathrm{O}_{24} \cdot 4 \mathrm{H}_{2} \mathrm{O}\right)+30$ $\mathrm{mL}$ ascorbic acid solution $\left(\mathrm{C}_{6} \mathrm{H}_{8} \mathrm{O}_{6}\right)$ was added at room temperature. The mixture was thoroughly homogenized, and the concentration of phosphorus (in $\mathrm{mg} / \mathrm{L}$ ) was measured after 10 minutes reaction time. Set wavelength for phosphorus was $880 \mathrm{~nm}$. Meanwhile, reagent blank was prepared by treating distilled water in the same way as sample. This served as quality control procedure. The blank readings were then subtracted from sample readings in order to eliminate interferences.

\section{Determination of bacterial and fungal counts}

Salmonella-Shigella, Nutrient and Potato dextrose agar were used for the determination of Salmonella-Shigella, total heterotrophic bacteria and total fungi counts. Manufacturers' instructions were considered while preparing the media. The Pour plate method [14] was adopted for determining microbial counts in palm wine. From the serially-diluted palm wine, $1 \mathrm{~mL}$ was plated in media. Thereafter, the agar plates were incubated with inversion at $37^{\circ} \mathrm{C}$ for $24-48$ hours for Salmonella-Shigella and total heterotrophic bacteria. Meanwhile, total fungi counts were incubated at $30{ }^{\circ} \mathrm{C}$ for 3-4 days. Colonies that grew in the media after incubation were enumerated and expressed as colony forming units (CFU) per $\mathrm{mL}$ of palm wine.

\section{Statistical analysis}

The statistical analysis was carried out using statistical package for social sciences (SPSS) software. Data was expressed as mean \pm standard deviation, and significant variations across the various locations were established using one way analysis of variance at $\mathrm{p}<$ 0.05 . Where significant difference occurred, Tukey HSD pair-wise test was used to discern the source of the observed variation. 
Table 1. Level of some physical and chemical constituents of palm wine in Wilberforce Island, Bayelsa state, Nigeria

\begin{tabular}{|c|c|c|c|c|c|c|c|c|c|}
\hline Locations & Sodium, mg/L & potassium, mg/L & Calcium, mg/L & $\begin{array}{c}\text { Magnesium, } \\
\mathrm{mg} / \mathrm{L}\end{array}$ & pH & Conductivity, $\mu \mathrm{S} / \mathrm{cm}$ & Specific gravity & $\begin{array}{c}\text { Total Nitrogen, } \\
\%\end{array}$ & $\begin{array}{c}\text { Available } \\
\text { phosphorus, } \\
\text { mg/L }\end{array}$ \\
\hline A & $9.177 \pm 0.062 \mathrm{a}$ & $14.807 \pm 0.118 b$ & $39.453 \pm 0.147 d$ & $7.652 \pm 0.125 b$ & $3.600 \pm 0.100 \mathrm{a}$ & $8416.667 \pm 28.868 \mathrm{e}$ & $1.002 \pm 0.001 \mathrm{ab}$ & $0.183 \pm 0.003 c$ & $0.057 \pm 0.006 \mathrm{c}$ \\
\hline B & $11.030 \pm 0.026 \mathrm{~b}$ & $13.842 \pm 0.037 \mathrm{a}$ & $33.550 \pm 0.298 \mathrm{c}$ & $9.126 \pm 0.107 \mathrm{c}$ & $3.767 \pm 0.115 \mathrm{a}$ & $8816.667 \pm 28.868 f$ & $0.998 \pm 0.001 \mathrm{a}$ & $0.216 \pm 0.002 f$ & $0.080 \pm 0.010 \mathrm{e}$ \\
\hline $\mathrm{C}$ & $10.981 \pm 0.031 b$ & $14.690 \pm 0.210 \mathrm{~b}$ & $17.788 \pm 0.168 \mathrm{a}$ & $6.403 \pm 0.522 \mathrm{a}$ & $3.700 \pm 0.100 \mathrm{a}$ & $5750.000 \pm 0.000 \mathrm{a}$ & $1.005 \pm 0.000 \mathrm{abc}$ & $0.131 \pm 0.000 \mathrm{a}$ & $0.020 \pm 0.000 \mathrm{a}$ \\
\hline $\mathrm{D}$ & $11.012 \pm 0.033 b$ & $15.634 \pm 0.041 \mathrm{c}$ & $39.539 \pm 0.330 \mathrm{~d}$ & $7.820 \pm 0.062 b$ & $3.733 \pm 0.058 \mathrm{a}$ & $7016.667 \pm 28.868 \mathrm{c}$ & $1.013 \pm 0.003 c$ & $0.202 \pm 0.002 \mathrm{e}$ & $0.073 \pm 0.006 \mathrm{de}$ \\
\hline $\mathrm{E}$ & $10.991 \pm 0.061 b$ & $15.351 \pm 0.245 \mathrm{c}$ & $41.297 \pm 0.364 \mathrm{e}$ & $7.653 \pm 0.189 b$ & $3.767 \pm 0.153 \mathrm{a}$ & $6150.000 \pm 132.288 \mathrm{~b}$ & $1.007 \pm 0.006 \mathrm{abc}$ & $0.152 \pm 0.004 \mathrm{~b}$ & $0.043 \pm 0.006 \mathrm{~b}$ \\
\hline F & $10.944 \pm 0.109 b$ & $14.596 \pm 0.518 b$ & $27.392 \pm 0.584 b$ & $9.592 \pm 0.487 \mathrm{c}$ & $3.600 \pm 0.100 \mathrm{a}$ & $8000.000 \pm 0.000 \mathrm{~d}$ & $1.010 \pm 0.010 \mathrm{bc}$ & $0.192 \pm 0.003 \mathrm{~d}$ & $0.063 \pm 0.006 \mathrm{~cd}$ \\
\hline
\end{tabular}

Data is expressed as mean \pm standard deviation; Different letters along the column indicate significant variations according to Tukey HSD statistics.

Table 2. Microbial counts of palm wine sold in Wilberforce Island, Bayelsa state, Nigeria

\begin{tabular}{|l|c|c|}
\hline Locations & THB $\times 10^{3} \mathrm{CFU} / \mathrm{ml}$ & TF $\times 10^{3} \mathrm{CFU} / \mathrm{ml}$ \\
\hline A & $5.600 \pm 1.442 \mathrm{~b}$ & $5.867 \pm 1.901 \mathrm{a}$ \\
\hline B & $3.933 \pm 0.850 \mathrm{ab}$ & $9.033 \pm 0.757 \mathrm{~b}$ \\
\hline C & $17.133 \pm 2.237 \mathrm{c}$ & $21.633 \pm 0.808 \mathrm{e}$ \\
\hline D & $5.667 \pm 0.907 \mathrm{~b}$ & $17.433 \pm 1.305 \mathrm{~d}$ \\
\hline E & $15.767 \pm 1.429 \mathrm{c}$ & $8.600 \pm 1.418 \mathrm{ab}$ \\
\hline F & $2.620 \pm 0.366 \mathrm{a}$ & $13.200 \pm 2.914 \mathrm{c}$ \\
\hline
\end{tabular}

Data is expressed as mean \pm standard deviation; different letters along the column indicate significant variations according to Duncan statistics

Table 3. Pearson Correlation of the physicochemical characteristics of palm wine sold in Wilberforce Island, Bayelsa state, Nigeria

\begin{tabular}{|l|c|c|c|c|c|c|c|c|c|}
\hline Parameters & $\mathrm{Na}$ & $\mathrm{K}$ & $\mathrm{Ca}$ & $\mathrm{Mg}$ & $\mathrm{pH}$ & Cond & $\mathrm{SP}$ & $\mathrm{TON}$ & $\mathrm{P}$ \\
\hline $\mathrm{Na}$ & 1 & & & & & & & & \\
\hline $\mathrm{K}$ & .003 & 1 & & & & & & & \\
\hline $\mathrm{Ca}$ & -.318 & .407 & 1 & & & & & & \\
\hline $\mathrm{Mg}$ & .156 & -.418 & .176 & 1 & & & & & \\
\hline $\mathrm{pH}$ & .400 & .212 & .138 & -.081 & 1 & & & & \\
\hline $\mathrm{Cond}$ & -.406 & $-.554^{*}$ & .285 & $.720^{* *}$ & -.221 & 1 & & & \\
\hline $\mathrm{SP}$ & .251 & .458 & .029 & .050 & -.118 & -.351 & 1 & & \\
\hline $\mathrm{TON}$ & -.036 & -.264 & .431 & $.753^{* *}$ & -.041 & $.837^{* *}$ & -.074 & 1 & \\
\hline $\mathrm{P}$ & .002 & -.207 & $.515^{*}$ & $.735^{* *}$ & -.105 & $.763^{* *}$ & .002 & $.966^{* *}$ & 1 \\
\hline
\end{tabular}

**. Correlation is significant at the 0.01 level (2-tailed)

*. Correlation is significant at the 0.05 level (2-tailed).

\section{Results}

Table 1 shows some of the physical and chemical characteristics of palm wine in Wilberforce Island, Bayelsa state, Nigeria. Macro nutrients found in the palm wine ranged from $6.403-9.592 \mathrm{mg} / \mathrm{L}$, $17.788-41.292 \mathrm{mg} / \mathrm{L}, 13.842-15.631 \mathrm{mg} / \mathrm{L}$ and $9.177-11.030 \mathrm{mg} / \mathrm{L}$ for magnesium, calcium, potassium and sodium respectively. There were significant variations at $\mathrm{p}<0.05$ across the various locations for each macro nutrient. However, sodium showed no significant variation across locations except for samples purchased from location A.

The $\mathrm{pH}$, conductivity, specific gravity, total nitrogen and available phosphorus of palm wine ranged from 3.600-3.767, 5750.000$8816.667 \mu \mathrm{S} / \mathrm{cm}, 0.998-1.010,0.131-0.216 \%$ and $0.020-0.063 \mathrm{mg} / \mathrm{L}$ respectively. Statistically, there were significant discrepancies at $\mathrm{p}<$ 0.05 for each parameter across different locations. However, this is with the exception of $\mathrm{pH}$ which showed no statistical deviation.

Table 2 presents the microbial density of palm wine sold in Wilberforce Island, Bayelsa state, Nigeria. The total heterotrophic bacteria and total fungi counts ranged from $2.620 \times 103-1.713 \times 104$ $\mathrm{CFU} / \mathrm{mL}$ and 5.867-2.163 x $104 \mathrm{CFU} / \mathrm{mL}$ respectively. Statistically, there was significant deviation $(\mathrm{p}<0.05)$ in the various locations for both parameters under consideration. Salmonella and Shigella counts were not detected in the palm wine.
Table 3 shows the Pearson correlation of the physicochemical characteristics of palm wine in Wilberforce Island, Bayelsa state, Nigeria. Potassium weakly correlates with conductivity $(\mathrm{r}=-0.554)$ at $\mathrm{p}<0.05$. Calcium weakly correlates with potassium $(\mathrm{r}=0.515)$ at $\mathrm{p}<0.05$. Magnesium strongly correlates with conductivity $(\mathrm{r}=0.720)$, total nitrogen $(\mathrm{r}=0.753)$, phosphorus $(\mathrm{r}=0.735)$. Conductivity strongly correlates with total nitrogen $(\mathrm{r}=0.837)$, phosphorus $(\mathrm{r}=0.763)$ at $\mathrm{p}<$ 0.01 . Total nitrogen strongly correlates with phosphorus $(\mathrm{r}=0.966)$ at $\mathrm{p}<0.01$.

\section{Discussion}

For magnesium, calcium, potassium and sodium, the observed significant variation may be attributed to the condition of palm wine prior to sampling and analysis. This may have resulted from its spontaneous fermentation which tends to alter several biochemical parameters of palm wine. The values obtained in this study differ from concentrations previously reported in palm wine from different states of Nigeria including Enugu [15], Abia [4], Bayelsa and Delta States [16]. The observed deviation of current results may be due to difference in palm species been tapped for wine. It could also be due to the characteristics of soil in which palm is cultivated. Basically, these macronutrients play an essential role in the overall well-being of living organisms $[11,17,18]$. Deficiency of these nutrients could also be detrimental to the overall functioning of the human body. For instance, the deficiency of calcium may lead to poor bone formation and growth, as well as milk fever, thereby causing adverse health effects. As recommended by Standard Organization of Nigeria (SON), the approved concentration of magnesium and sodium in potable water is $20 \mathrm{mg} / \mathrm{L}$ and $200 \mathrm{mg} / \mathrm{L}$ respectively.

For conductivity, specific gravity, total nitrogen and available phosphorus, there were significant variations at $p<0.05$ across the different locations. According to Aigberua and Izah [12], phosphorus is crucial for proper functioning of the kidney, muscle contractions, normal heartbeat and nerve signalling. Based on the result of this study, there is no obvious health risk associated with available phosphorus in palm wine.

The trend of $\mathrm{pH}$ and specific gravity recorded in this study has some similarity with the work of other authors. Falegan and Akoja [3] reported $\mathrm{pH}$ range of 4.490-5.230 in palm wine sold in Ekiti state. Afolabi and Owoola [19] reported $\mathrm{pH}$ level of 3.700 within 24 hours of purchase, and increasing acidity with $\mathrm{pH}$ of 3.370 after 360 hours of spontaneous fermentation. Dibofori-Orji and Ali [1] reported the decrement of $\mathrm{pH}$ from $(6.200-6.400)$ to $(3.100-3.330)$, as well as increasing conductivity trend, rising from $\left(800.000-1200.000 \mu \mathrm{Scm}^{-1}\right)$ to (2520.000-2812.000 $\left.\mu \mathrm{Scm}^{-1}\right)$. Adeleke and Abiodun [20] reported $\mathrm{pH}$ and specific gravity of 4.300 and 1.039 respectively for palm wine sold in some locations of Osun state, Nigeria. Basically, as palm wine 
fermentation progresses, most of the physicochemical characteristics including $\mathrm{pH}$ and conductivity become altered [21]. However, this study reflected fairly stable $\mathrm{pH}$ and specific gravity. This is indication that the microbes responsible for spontaneous fermentation have converted a significant amount of sugar in palm wine to alcohol. Therefore, specific gravity provides preliminary information about the sugar and ethanol content of palm wine. Conductivity level also gives information about the composition of minerals such as macro nutrients (calcium, potassium, magnesium and sodium) in palm wine. Generally, the recorded conductivity exceeds limits permitted for potable drinking water. Nevertheless, it may not pose any considerable health risk. In addition, the acidic $\mathrm{pH}$ of palm juice may cause stomach ache since extreme acidic $\mathrm{pH}$ often results in stomach pain.

Nitrogen is an essential element that is required for the utmost functioning of all forms of life. The unavailability or deficiency of nitrogen has been known to cause discoloration and stunted growth in plants [22]. As such, it is necessary to maintain balance in the way nitrogen is applied for increased crop yield in order to reduce the possibility of food toxicity and forestall the incidence of food chain biomagnifications to toxic levels.

The microbial density exceeds WHO/SON level of $10^{2}$ for drinking water. However, it is within the tolerable limits $\left(10^{4}\right.$ to $\left.10^{5}\right)$ for microbial counts (total heterotrophic bacteria and total fungi) in foods as specified by the International Commission on Microbiological Specifications for Foods [23]. The observed significant variation in microbial density of palm wine could be due to differences in the level of hygiene practiced by divergent vendors. Again, the methods of packaging may have contributed to the microbial quality of palm wine. Typically, most vendors in the study area use discarded empty plastic bottles of water for storing and selling the drink to retail consumers who purchase in smaller quantities. The cans are picked from several places including ceremonial grounds, schools, hospital, amongst others.

The microbial density obtained from the study has some relationship with previous studies on microbial population in palm wine sold in some Nigerian states of Abia [2,6] and Ekiti [3]. Afolabi and Owoola [19] reported yeasts (Saccharomyces cerevisiae) count in the range of $5.460 \times 10^{4} \mathrm{CFU} / \mathrm{mL}$ at day one to $3.000 \times 10^{2} \mathrm{CFU} / \mathrm{mL}$ at day twenty-two. This implies that continuous fermentation decreases the population of yeasts in palm wine. Among the groups of microbes found in palm wine, fungi (especially yeasts such as Saccharomyces cerevisiae) is the major microbial species which aids the spontaneous fermentation of sugar to ethanol.

The correlation trends observed in this study indicates a diverse source of contaminants. The macro nutrients may have been assimilated from the soil. On the other hand, the observed positive significant relationships suggest similar emissions or source contaminants [24].

\section{Conclusion}

The study evaluated the microbial density and associated physicochemical properties of palm wine in Wilberforce Island, Nigeria and indicated that microbial counts (total heterotrophic bacteria and total fungi) are within tolerable limits for food. However, values exceeded the drinking water standard of $1.000 \times 102 \mathrm{CFU} /$ $\mathrm{ml}$. Correlations of physicochemical parameters revealed a divergent source of contaminants. Notwithstanding, it is crucial to sensitize local vendors and the public on good hygiene practices, particularly during food handling and storage, as this will likely forestall potential public health implications associated with the consumption of palm wine.

\section{Acknowledgements}

The authors wish to thank Analytical Concept Limited Port Harcourt, Nigeria, for providing the laboratory facilities to carry out this research.

\section{References}

1. Dibofori-Orji AN, Ali ST (2019) Physicochemical analysis of palm wine. J Pharmacogn Phytochem 8: 417-421.

2. Nwachukwu I, Ekaiko MU, Stephen C (2016) Microbiological Quality of Palm Wine (Elaeis guineensis and Raphia hookeri) Sold Within Aba Metropolis, Abia State, South Eastern Nigeria. Euro J Biotechnol Genetic Eng 3: 38-44.

3. Falegan CR, Akoja SO (2014) Microbiological and physicochemical studies of two Nigerian fermented alcoholic drinks (palmwine and burukutu) in Ekiti state, Nigeria. Euro J Food Sci Technol 2: 13-22.

4. Nkemnaso OC, Ifeanyi N (2018) Microbiological and Nutritional Status of Palm Wine from Umudike and Its Environs. Intern J Bioinform Biomed Eng 4: 62-69

5. Obi CN, Ogbulie JN, Nkwo AM (2015) Assessment of microbial growth and surviva in fresh rafia palmwine from Umuariaga community, Ikwuano L. G. A. Abia State, Nigeria. Inter J Curr Microbiol App Sci 4: 484-494.

6. Nwachukwu IN, Ibekwe VI, Nwabueze RN, Anyanwu BN (2006) Characterisation of palm wine yeast isolates for industrial utilization. Afr J Biotechnol 5: 1725-1728.

7. Otu-Bassey IB, Mbah M, Ogba OM, Sunday TJ (2017) Entero bacterial pathogens associated with palm wine sold in Calabar metropolis. Merit Res J Microbiol Biol Sci 5: $022-025$.

8. Andrew CE, Bariweni PA (2018) Opportunity Costs of Forest Conservation in Wilberforce Island, Niger Delta, Nigeria. J Appl Sci Environ Manage 22: 1965-1968.

9. Ohimain EI, Izah SC, Otobotekere D (2014) Selective impacts of the 2012 water floods on the vegetation and wildlife of Wilberforce Island., Nigeria. Intern J Environ Monit Anal 2: 73-85.

10. Zige DV, Ohimain EI, Sridhar MKC, Ogbopuru GE (2013) A community based screening of asymptomatic typhoid carriers in Wilberforce Island., Bayelsa state., Nigeria. Inter J Health Sci Res 3:119-126.

11. Aigberua AO, Alagoa KJ, Izah SC (2018) Macro Nutrient Composition in Selected Seasonings used in Nigeria. MOJ Food Process Technol 6: 00155.

12. Aigberua AO, Izah SC (2019) pH Variation, Mineral Composition and Selected Trace Metal Concentration in Some Liquid Herbal Products Sold in Nigeria. Intern J Res Studies Biosci 7: 1-8.

13. American Public Health Association (APHA) (2017) Standard Methods for the Examination of Water and Wastewater, $23^{\text {rd }}$ Ed. American Public Health Association, Washington, DC.

14. Benson HJ (2002) Microbiological Applications: Laboratory Manual in General Microbiology. complete version, 5th edition. McGaraw-Hill, New York.

15. Ape DI, John NS, Nwafor EC, Ekpe IO (2015) Determination of Trace and Major Elements in Palm wine from Industrial and Non-industrial Areas of Enugu State Nigeria. Intern J Multidiscipl Sci Eng 6: 18-22.

16. Ihedioha JN, Okoye COB, Onyechi UA (2014) Health risk assessment of zinc, chromium and nickel from cow meat consumption in an urban Nigerian population. Inter J Occup Environ Health 20: 281-288.

17. Izah SC, Bassey SE, Ohimain E (2017) Cyanide and Macro-Nutrients Content of Saccharomyces cerevisiae Biomass Cultured in Cassava Mill Effluents. Intern J Microbiol Biotechnol 2: 176-180.

18. Palacios C (2006) The Role of Nutrients in Bone Health, from A to Z. Crit Rev Food Sci Nutr 46: 621-628.

19. Afolabi FT, Owoola AT (2019) Microbiological and Physicochemical Changes in Palm Wine Subjected To Spontaneous Fermentation During Storage. The Intern J Biotechnol 8: $48-58$

20. Adeleke RO, Abiodun OA (2010) Physico-chemical properties of commercial local beverages in Osun state, Nigeria. Pak J Nutr 9: 853-855.

21. Lucky GB, Cookey GA, Ideriah TJK (2017) Physicochemical and Nutritional Parameters in Palm Wine from Oilpalm Tree (Elaies guineensis) and Raffia Palm (Raphia hookeri) in South-South Nigeria. Chem Res J 2:146-152.

22. Aczel M (2019) What is the Nitrogen Cycle and Why is it Key to Life? Front Young Minds 7: 41. 
Richard G (2021) Microbial density and associated physicochemical properties of palm wine in Wilberforce Island, Nigeria

23. International Commission on Microbiological Specifications for Foods (ICMSF) (1996) Microorganisms in Foods 5: Microbiological Specifications of Pathogens.
24. Taiwo AM, Aigbodion CO, Ojekunle OZ, Akinhanmi TF (2020) Health Risk Assessment of Metals in Selected Drinks from Abeokuta, Southwestern Nigeria. Biol Trace Elem Res 197: 694-707

Copyright: (C2021 Richard G. This is an open-access article distributed under the terms of the Creative Commons Attribution License, which permits unrestricted use, distribution, and reproduction in any medium, provided the original author and source are credited. 